\title{
Skin Cancer Prevention, Tanning and Vitamin D: A Content Analysis of Print Media in Germany and Switzerland
}

\author{
Daphne Reinau ${ }^{a, b} \quad$ Christoph R. Meier ${ }^{a, b, e}$ Ralf Blumenthal ${ }^{f}$ \\ Christian Surber ${ }^{c, d}$ \\ a Basel Pharmacoepidemiology Unit, Division of Clinical Pharmacy and Epidemiology, Department of \\ Pharmaceutical Sciences, University of Basel, and ${ }^{\mathrm{b}}$ Hospital Pharmacy and ${ }^{\mathrm{C}}$ Department of Dermatology, \\ University Hospital Basel, Basel, and dDepartment of Dermatology, University Hospital Zurich, Zurich, \\ Switzerland; 'Boston Collaborative Drug Surveillance Program, Boston University School of Public Health, \\ Lexington, Mass., USA; ${ }^{f}$ Berufsverband der Deutschen Dermatologen e.V., Berlin, Germany
}

\section{Key Words}

Skin neoplasms · Sunburn · Prevention · Ultraviolet rays ·

Sunscreening agents $\cdot$ Solaria $\cdot$ Vitamin $D \cdot$ Media .

Newspapers · Magazines

\begin{abstract}
Background: Print media are a major source of health information. Objectives: To analyse press coverage related to skin cancer prevention. Methods: We conducted a content analysis of print media articles pertaining to skin cancer prevention, solaria and vitamin D published in Germany and Switzerland over a 1-year period between 2012 and 2013. Results: Overall, 2,103 articles were analysed. Applying sunscreen was by far the most common sun protection recommendation. A considerable number of articles on solaria and vitamin $\mathrm{D}$ advocated exposure to ultraviolet radiation to enhance physical appearance and vitamin D photosynthesis, often without mentioning any precaution measures. In total, $26.8 \%$ of the articles contained misleading or erroneous statements mostly related to sunscreen use and vitamin $D$ issues. Conclusions: Print media can serve as powerful edu-
\end{abstract}

cation tools to foster skin cancer prevention. However, misleading or erroneous reports may negatively impact sunsafe behaviour.

c) 2015 S. Karger AG, Basel

\section{Introduction}

Skin cancer represents the most frequent malignancy in Caucasian populations [1], although it is largely preventable by minimising exposure to solar and artificial ultraviolet radiation (UVR) [2,3]. Common barriers to primary prevention (sun protection, avoidance of indoor tanning) include lack of awareness, perceived inconvenience, the pursuit of a tanned skin as well as widely unsubstantiated concerns about the safety of sunscreens and insufficient UVR-mediated vitamin D synthesis [4-7].

A summary of our results was presented in a plenary session and as a poster at the 15th World Congress on Cancers of the Skin, Edinburgh, September 3-6, 2014, and was subsequently published as an abstract in the British Journal of Dermatology.

\section{KARGER}

E-Mail karger@karger.com

www.karger.com/drm (c) 2015 S. Karger AG, Base

$1018-8665 / 15 / 2321-0002 \$ 39.50 / 0$
Prof. Dr. phil. nat. Christian Surber

Department of Dermatology, University Hospital Basel

Petersgraben 4

$\mathrm{CH}-4031$ Basel (Switzerland)

E-Mail christian.surber@ unibas.ch 
Print media are a major source of health information for the general public [8-11], playing a crucial role in improving knowledge, shaping attitudes and potentially modifying behaviours regarding sun protection and tanning $[12,13]$. Considering that skin cancer is readily detectable and highly curable at an early stage, the popular press is moreover indispensable for the widespread communication of secondary prevention strategies (skin selfexaminations, dermatological screening) [14]. Hence, newspapers and magazines can serve as inexpensive, powerful education tools to foster skin cancer prevention on multiple levels. However, misleading or erroneous reports hold the danger to create confusion and may even negatively impact sun-safe behaviour. In this context, particular mention must be made of unbalanced statements promoting intentional UVR exposure to enhance cutaneous vitamin $\mathrm{D}$ photosynthesis, albeit sufficient amounts of the vitamin can be obtained from diet, supplements and incidental protected sun exposure [15].

To gain a detailed insight into the content and quality of press coverage pertaining to skin cancer prevention and related topics (solaria, vitamin D), we conducted a comprehensive analysis of respective print media articles published in Germany and Switzerland over a 1-year period between 2012 and 2013.

\section{Methods}

\section{Sample Selection}

Two professional media-monitoring agencies (Rothenburg \& Partner Medienservice GmbH, Germany, and ARGUS der Presse AG, Switzerland) prospectively identified print media articles pertaining to skin cancer prevention, solaria and vitamin $\mathrm{D}$ published in Germany and Switzerland over a period of 12 months between 2012 and 2013. The monitoring programmes covered the content from several thousand daily and weekly newspapers, general interest, special interest and specialist magazines. The complex search profiles included terms like 'skin cancer', 'malignant melanoma', non-melanoma skin cancer', 'sun protection', 'sunscreen', 'UV filters', 'solarium' and 'vitamin D', as well as corresponding synonyms.

We entirely read all retrieved articles and excluded them from further analysis if they focused on portrayal of individual skin cancer patients, cancer statistics, therapy (skin cancer, sunburn), 'sun allergy' or photosensitising substances. We did not consider articles with fewer than 4 relevant sentences, medical press, reader's letters, announcements and reports of events, and advertisements for specific products or institutions.

\section{Coding Procedure}

Using a standardised coding sheet, one author (D.R.) assessed the articles' descriptive characteristics (primary topic, publication source, length, authorship, target audience), content (presence or absence of predefined information) and quality (correct, misleading or erroneous information). Articles were defined as 'misleading' if they contained at least one statement that could lead readers to false conclusions without being demonstrably wrong (e.g. ambiguous wording, omission of important facts), and as 'erroneous' if they contained at least one statement that was factually incorrect according to the current state of science. All statements coded as misleading or erroneous were re-evaluated by a second author (C.S.).

\section{Statistical Analysis}

We summarised the extracted data using descriptive statistics. Where appropriate, we calculated frequency distributions separately by the articles' primary topic (i.e. skin cancer primary prevention, secondary prevention, solaria and vitamin $\mathrm{D}$ ).

In addition, we set up a multivariate logistic regression model to examine potential associations between the quality of the articles (outcome: misleading or erroneous information) and selected predictor variables. These comprised the articles' country of publication, publication source, circulation, length and authorship. Odds ratios (ORs) were adjusted for all variables in the model and are presented with the corresponding 95\% confidence interval (CI).

All analyses were performed using SAS 9.3 software (SAS Institute, Cary, N.C., USA), and statistical significance was defined at the a-level of 0.05 .

\section{Results}

Table 1 displays the characteristics of the 2,103 articles included for analysis. The seasonal frequency of media coverage by primary topic is illustrated in figure 1 .

\section{Primary Prevention}

In the 1,396 articles on primary prevention, the most frequently cited adverse effects of UVR exposure were sunburn (64.8\%) and skin cancer (61.7\%; malignant melanoma: $18.6 \%$; non-melanoma skin cancer: $14.0 \%$; not specified: $41.5 \%)$, followed by premature skin ageing $(28.4 \%)$ and eye disorders (5.3\%). Person groups and areas at increased risk of suffering UV damage were named in 54.2 and $16.0 \%$ of the texts, respectively (fig. 2). Only a few articles pointed out that UVR may penetrate into the shade (12.9\%), through clouds $(8.5 \%)$, window glass $(7.1 \%)$ and the water surface $(2.6 \%)$. No more than $3.1 \%$ mentioned the UV Index as a measure of the current or forecast UVR intensity at a given time and location [16].

Artificial tanning was discouraged in $10.7 \%$ of articles on primary prevention, and $2.7 \%$ stated that a suntan is a manifestation of cutaneous photodamage. On the other hand, 6.0 and $2.0 \%$ associated a tanned skin with terms like 'attractive' and 'healthy', respectively. 
Table 1. Characteristics of the analysed print media articles

\begin{tabular}{|c|c|}
\hline & Articles, n (\%) \\
\hline Total & $2,103(100.0)$ \\
\hline \multicolumn{2}{|l|}{ Primary topic } \\
\hline Primary skin cancer prevention & $1,396(66.4)^{1}$ \\
\hline Secondary skin cancer prevention & $267(12.7)^{1}$ \\
\hline Solaria & $315(15.0)$ \\
\hline Vitamin D & $320(15.2)$ \\
\hline \multicolumn{2}{|l|}{ Country of publication } \\
\hline Germany & $1,866(88.7)$ \\
\hline Switzerland & $237(11.3)$ \\
\hline \multicolumn{2}{|l|}{ Publication source } \\
\hline Daily and weekly newspapers & $1,643(78.1)$ \\
\hline General interest magazines & $314(14.9)$ \\
\hline Special interest magazines & $129(6.1)$ \\
\hline Other & $17(0.8)$ \\
\hline \multicolumn{2}{|l|}{ Circulation } \\
\hline$<25,000$ & $598(28.4)$ \\
\hline $25,000-99,999$ & $718(34.1)$ \\
\hline $100,000-199,999$ & $408(19.4)$ \\
\hline$\geq 200,000$ & $373(17.7)$ \\
\hline Unknown & $6(0.3)$ \\
\hline \multicolumn{2}{|l|}{ Article length } \\
\hline Short (approx. $<0.5$ page) & $723(34.4)$ \\
\hline Medium (approx. $0.5-1.5$ pages) & $1,322(62.9)$ \\
\hline Long (approx. $>1.5$ pages) & $58(2.8)$ \\
\hline \multicolumn{2}{|l|}{ Authorship } \\
\hline Journalist & $1,609(76.5)$ \\
\hline Health professional & $125(5.9)$ \\
\hline Unknown & $369(17.6)$ \\
\hline \multicolumn{2}{|l|}{ Target audience } \\
\hline General public & $1,753(83.4)$ \\
\hline Parents & $214(10.2)$ \\
\hline Children and adolescents & $57(2.7)$ \\
\hline Other & $79(3.8)$ \\
\hline
\end{tabular}

Specific sun protection recommendations were made in 1,287 articles (table 2; fig. 3). Of these, $22.3 \%$ exclusively suggested the use of sunscreen.

\section{Secondary Prevention}

Of the 267 articles on secondary prevention, $64.8 \%$ recommended skin self-examinations to detect early signs of skin cancer. However, $89.6 \%$ of these did not explain how to perform self-examination, and $11.0 \%$ did not describe skin cancer symptoms. The recommendations regarding skin cancer screening by a health professional differed between Germany and Switzerland, with

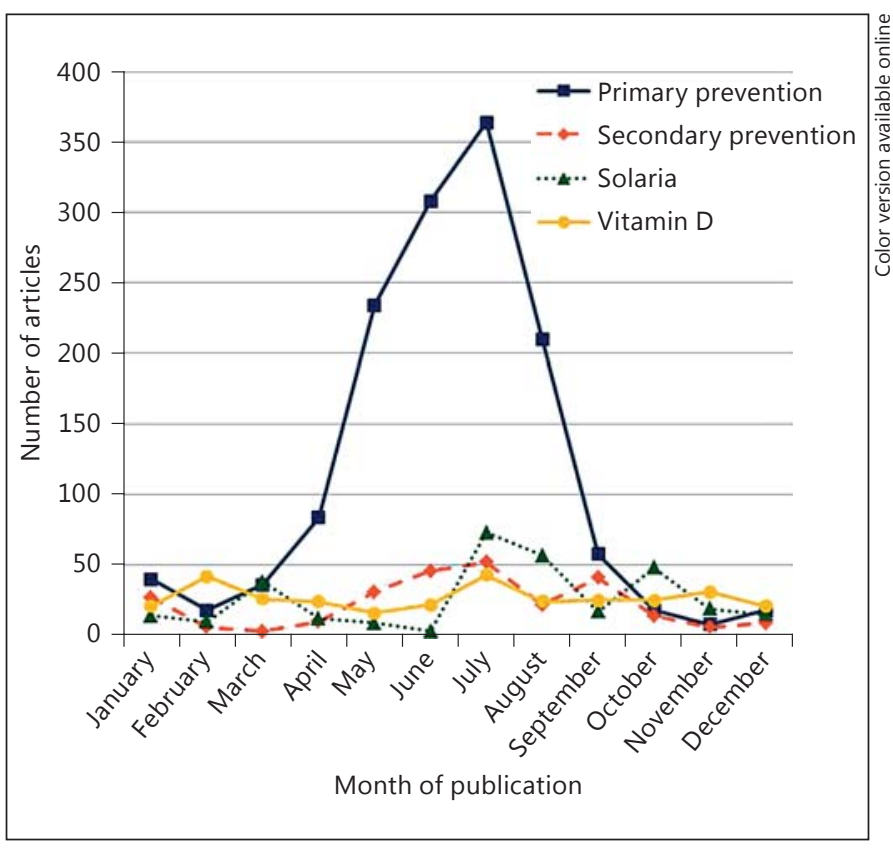

Fig. 1. Seasonal print media coverage of skin cancer prevention, solaria and vitamin D.

$66.2 \%$ of German and $23.1 \%$ of Swiss articles on secondary prevention advocating routine dermatological screening for the general adult population.

\section{Solaria}

Of the 315 articles focusing on solaria, 93.3\% mentioned potential adverse health effects (skin cancer: $87.9 \%$; premature skin ageing: 16.5\%; skin burn: $15.6 \%$; eye disorders: $14.6 \%$ ). Yet 7.0 and $5.1 \%$ promoted artificial tanning to enhance cutaneous vitamin D synthesis and physical appearance, respectively.

\section{Vitamin D}

Of the 320 articles focusing on vitamin D, $83.1 \%$ recommended UVR exposure to achieve healthy vitamin D levels (5.9\% encouraged the use of solaria). Of these, $12.0 \%$ neither stated that UVR may present a hazard to health nor that vitamin D photosynthesis requires only a relatively small amount of UVR. Furthermore, 17.5\% of all vitamin $\mathrm{D}$ articles emphasised that sunscreens may limit or even completely block vitamin D photosynthesis.

\section{Quality of Information}

In total, $26.8 \%$ of all analysed articles contained misleading or erroneous information (misleading state- 
Fig. 2. Frequency of references to person groups and areas at increased risk of suffering UV damage in articles on primary prevention.

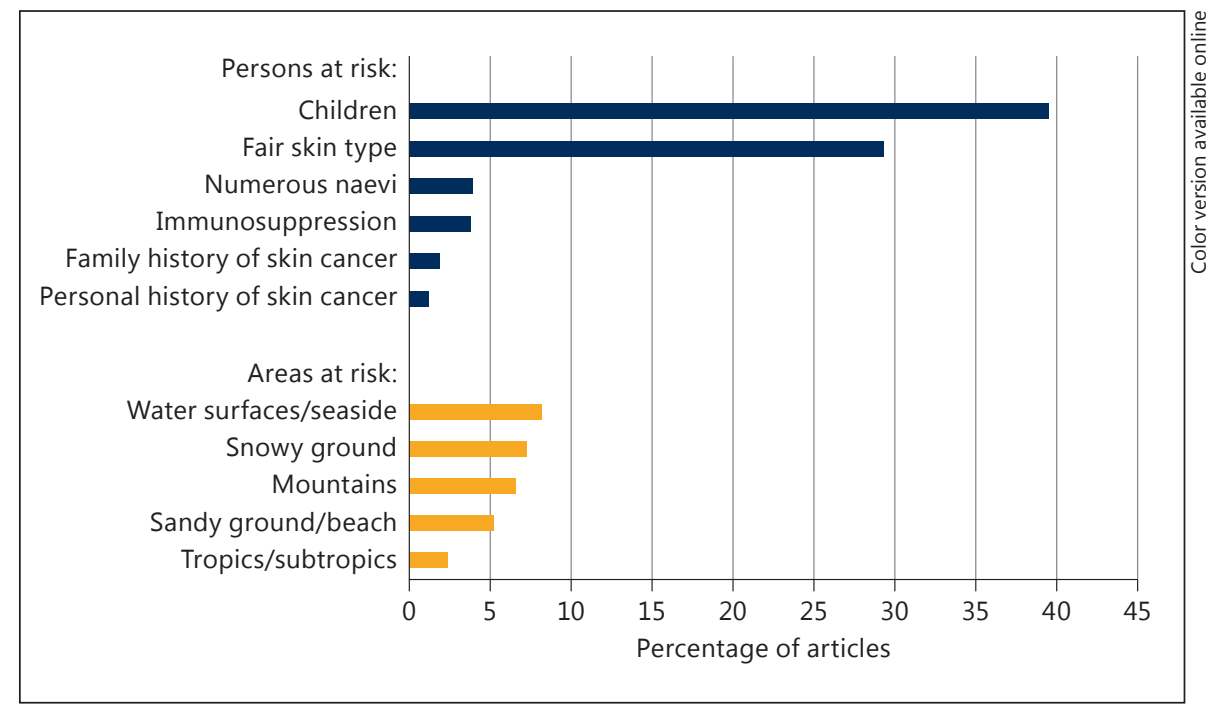

ments: 22.4\%; erroneous statements: 10.9\%). Table 3 shows the frequency of inaccuracies by topic and some illustrative examples along with our comments.

According to the multivariate model, articles published in general interest and special interest magazines were about twice as likely to contain misleading or erroneous information as articles published in daily or weekly newspapers (OR: 2.02, 95\% CI: 1.43-2.85 and OR: 1.87, 95\% CI: 1.18-2.96, respectively). Furthermore, the odds of misleading or erroneous information were increased for articles authored by health professionals compared to articles authored by journalists (OR: 2.14, 95\% CI: 1.413.24) and for long and medium articles compared to short articles (OR: 11.97, 95\% CI: 6.17-23.22 and OR: 5.47, 95\% CI: 4.13-7.23, respectively). The country of publication and the circulation did not significantly influence the articles' quality.

\section{Discussion}

The present study represents to our knowledge the most comprehensive content analysis of skin cancer-related print media to date and provides a unique insight into the way prevention messages issued by health organizations reach the public.

Before the 1930s, the association between UVR exposure and skin cancer was rarely mentioned in the popular press and virtually unknown to the general population [17]. Yet in the meantime, skin cancer primary prevention by UVR protection has become a frequently covered media topic, particularly during the summer months.

Print Media Coverage of Skin Cancer Prevention
Table 2. Frequency of specific sun protection recommendations

\begin{tabular}{lc}
\hline & Articles, $\mathrm{n}(\%)$ \\
\hline Any sun protection recommendation & $1,287(100.0)$ \\
Sunscreen & $1,225(95.2)$ \\
Recommendation of specific (minimum) SPF & $492(38.2)$ \\
Reference to regular reapplication & $397(30.8)$ \\
Reference to amount of application & $322(25.0)$ \\
Broad-spectrum sunscreen & $240(18.6)$ \\
Water-resistant sunscreen & $127(9.9)$ \\
Clothing & $777(60.4)$ \\
With integrated UV protection & $213(16.6)$ \\
Made of tightly woven fabric & $104(8.1)$ \\
Made of dark fabric & $76(5.9)$ \\
Made of synthetic fabric & $35(2.7)$ \\
Shade & $763(59.3)$ \\
Sun avoidance around noon & $523(40.6)$ \\
Protective headgear & $574(44.6)$ \\
Wide-brimmed or with neck flaps & $155(12.0)$ \\
Sunglasses & $354(27.5)$ \\
With UV protection & $150(11.7)$ \\
With wrap-around design or large lenses & $26(2.0)$ \\
Systemic sun protection & $45(3.5)$ \\
Diet (e.g. carrots, tomatoes) & $29(2.3)$ \\
Dietary supplements (e.g. $\beta$-carotene tablets) & $25(1.9)$ \\
\hline
\end{tabular}

$\mathrm{SPF}=$ Sun protection factor.

However, although we identified individual well-written and informative reports, the information content of the analysed articles was in general rather limited. Few authors reported that adequate UVR protection does not merely prevent sunburn and skin cancer, but also prema- 


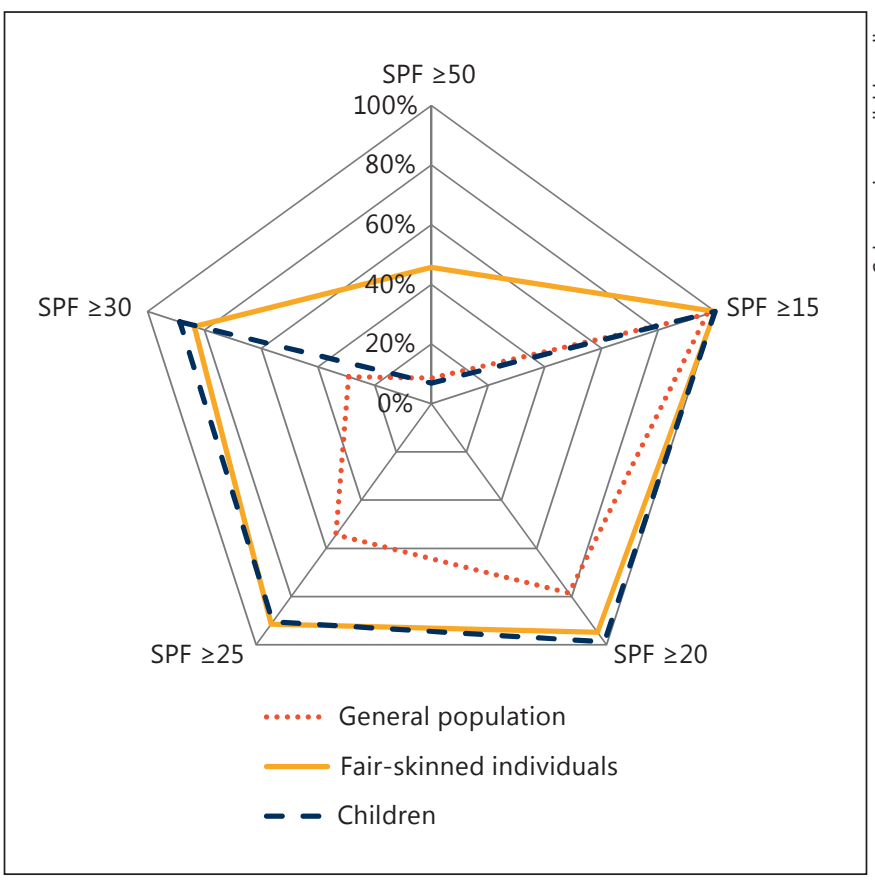

Fig. 3. Minimum sun protection factor (SPF) of sunscreens recommended in articles on primary prevention for the general population (adults of unspecified skin type), for fair-skinned individuals (Fitzpatrick skin type I/II), and for children; 100\% corresponds to all articles stating a (minimum) SPF for the respective target group.

ture skin ageing and eye disorders. Person groups and situations at increased risk of suffering UV damage were not routinely mentioned, and the UV Index as a communication tool of UVR intensity was hardly ever explained. Hence, it is not surprising that the awareness and understanding of the UV Index in Germany as well as in Switzerland was found to be very low $[18,19]$.

The use of a sunscreen was by far the most common and - in many cases - the sole sun protection recommendation made, even though seeking shade and covering up with clothing are assigned a more important role in the hierarchy of photoprotective strategies [20, 21]. Moreover, only a minority of articles contained detailed advice about what kind of sunscreen [sun protection factor (SPF), UVA protection, water resistance], clothing (fabric properties) and headgear (wide brim, neck flaps) best to use, and about how to apply sunscreen properly (amount and timing of application, reapplication). The recommended SPFs differed substantially, ranging from 10 to $50+$ for the general population (adults of unspecified skin type). This reflects in part the diverging SPF recommendations published by national and international cancer control and health agencies. To name a few examples, the Swiss Cancer League generally advises SPF $\geq 15$ [22], the Swiss Federal Office of Public Health recommends SPF $\geq 20$ [23], and the European Skin Cancer Foundation and the German Cancer Aid suggest SPF $\geq 25$ [24] and SPF $\geq 30$ [25], respectively.

Paradoxically, a noteworthy number of articles on skin cancer primary prevention promoted a suntanned skin as attractive or healthy, albeit it is well established that all tanning is a manifestation of DNA photodamage [26].

Skin cancer secondary prevention by skin self-examinations and dermatological screening receives relatively little attention in the press. Accordingly, a representative telephone survey in Germany revealed that in 2011 less than half of the adult population was aware that persons with statutory health insurance above the age of 35 years are entitled to a biennial skin cancer screening by a trained physician [27]. In a recent interview survey among German adults, 51\% reported having never had a medical check of pigmented naevi [28]. In Switzerland, routine skin cancer screening is neither generally recommended nor refunded by the health insurance, which may account for the country differences in the media coverage of this topic.

Despite the widely recognized health risks linked to indoor tanning, several newspapers and magazines still release articles which encourage the visit to solaria in order to acquire a tan and to boost vitamin D photosynthesis. Aside from recommending active exposure to a carcinogen, these articles ignore that tanning devices usually emit predominantly UVA, whereas the action spectrum for vitamin D formation lies in the UVB range [29].

Compared to solaria, natural sunlight is very efficient in inducing cutaneous vitamin D synthesis. Maximum vitamin D concentrations are already reached after exposure of a relatively small skin surface to solar UVR doses well below the minimal erythema dose. Thus, incidental protected sun exposure usually results in vitamin D levels considered sufficient to maintain musculoskeletal health and potentially to prevent extraskeletal disorders associated with vitamin D deficiency (e.g. certain internal cancers and autoimmune diseases). Alternatively, diet and oral supplements constitute non-carcinogenic, readily available sources of the vitamin - facts the media often fail to acknowledge $[15,30]$.

Recent evidence from Australia suggests that concurrently with an increase in media coverage of vitamin D $[31,32]$, an increasing proportion of the population reduces sun protection practices due to concerns about vitamin D insufficiency [33]. In view of the numerous 
Table 3. Frequency and illustrative examples of misleading or erroneous media statements by topic of inaccuracy

\begin{tabular}{llll}
\hline $\begin{array}{l}\text { Topic of } \\
\text { inaccuracy }\end{array}$ & $\begin{array}{l}\text { Articles, } \\
\mathrm{n}(\%)^{1}\end{array}$ & $\begin{array}{l}\text { Examples (original quotes from the articles translated } \\
\text { into English) }\end{array}$ & Comment \\
\hline $\begin{array}{l}\text { Sunscreen: } \\
\text { application }\end{array}$ & $139(24.6)$ & $\begin{array}{l}\text { The sunscreen only grants protection once a day which } \\
\text { is not prolonged by repeated application. That just } \\
\text { promotes buying! }\end{array}$ & $\begin{array}{l}\text { Although the reapplication of sunscreen does not extend the } \\
\text { provided protection time }{ }^{2} \text {, it is indispensable to compensate for } \\
\text { initial underapplication and to replace sunscreen that may have } \\
\text { been removed by sweat, water, towelling or friction with clothing } \\
\text { or sand [34]. } \\
\text { (Statement rated as misleading) }\end{array}$
\end{tabular}

Sunscreen: $\quad 137$ (24.3) You can calculate how long you can sunbathe without SPF danger. UVB protection factor multiplied by your own Under laboratory conditions ( $2 \mathrm{mg}$ sunscreen $/ \mathrm{cm}^{2} \mathrm{skin}$, no natural protection time. abrasion), the protection time ${ }^{2}$ of sunscreen-protected skin can be calculated by multiplying the sunscreen's SPF with the natural protection time of the unprotected skin (dependent on the skin phototype) [35]. Under real-world conditions, the protection time of sunscreen-protected skin is usually much shorter, because consumers apply insufficient amounts of sunscreen (typically $<1 \mathrm{mg} / \mathrm{cm}^{2}$ ) and fail to reapply the product after swimming and sweating [36-38].

(Statement rated as misleading)

SPF 20 is enough. It already absorbs 95\% of all UVB rays. Sunscreens with SPF 20 and SPF 40 filter out 95.0 and $97.5 \%$ of It is absurd to believe that SPF 40 protects you double as the erythemogenic UVR, respectively. Hence, the UVR dose that well as SPF 20. An additional protection is hardly measurable with sunscreens with a higher factor - they are just more expensive. penetrates into the skin and is responsible for UV damage is halved between SPF 20 and SPF 40 (5 vs. 2.5\%), i.e. the protection doubles between SPF 20 and SPF 40 [39]. (Statement rated as erroneous)

\begin{tabular}{lcl}
\hline $\begin{array}{l}\text { Sunscreen: } \\
\text { labelling } \\
\text { (excl. SPF) }\end{array}$ & $60(10.6)$ & $\begin{array}{l}\text { All sunscreen products nowadays guarantee a protection } \\
\text { from UVA and UVB rays. }\end{array}$ \\
\hline $\begin{array}{l}\text { Sunscreen: } \\
\text { safety }\end{array}$ & $67(11.9)$ & $\begin{array}{l}\text { Traditional sunscreens contain chemicals that are known } \\
\text { to be toxic. }\end{array}$
\end{tabular}

In Europe, adequate UVA protection is only guaranteed, if a sunscreen is labelled with the UVA logo [39]. (Statement rated as erroneous)

Before their approval, UV filters have to pass a thorough safety evaluation including studies on acute toxicity, (sub)chronic toxicity, reproductive toxicity, genotoxicity, photogenotoxicity, carcinogenicity, irritation, sensitization, phototoxicity and photosensitisation [40].

(Statement rated as erroneous)

$\begin{aligned} & \text { Sunscreen: } \\ & \text { other }\end{aligned} \quad 21(3.7)$
$\begin{aligned} & \text { Sunscreens protect you from sunburn, but not from skin } \\ & \text { cancer. }\end{aligned}$

Evidence from randomised controlled trials suggests that regular sunscreen use prevents cutaneous squamous cell carcinoma (including actinic keratosis) [41, 42] and malignant melanoma [43]. (Statement rated as erroneous)

$\begin{aligned} & \text { Protective } \\ & \text { clothing }\end{aligned} \quad 49(8.7) \quad \begin{aligned} & \text { Clothing with UV protection is good, but so is thin } \\ & \text { cotton clothing. }\end{aligned}$
Clothes with integrated UV absorbers are an excellent means of photoprotection. However, the protection provided by thin clothes made of cotton is limited [20].

(Statement rated as misleading)

\begin{tabular}{|c|c|c|}
\hline $\begin{array}{l}\text { Systemic sun } \\
\text { protection }\end{array}$ & $45(8.0)$ & $\begin{array}{l}\text { Someone who is going on holiday to a sunny place } \\
\text { should start eating fruit and vegetables with plenty of } \\
\beta \text {-carotene } 4 \text { weeks beforehand at the latest. }\end{array}$ \\
\hline
\end{tabular}

$\beta$-Carotene has proven effective in modestly increasing the skin's photoprotective capacities. Yet the achievement of relevant protection requires the intake of relatively high doses $(\sim 10 \mathrm{mg} /$ day $)$ over at least 10 weeks [44].

(Statement rated as misleading)

\begin{tabular}{llll}
\hline Sunbathing & $94(16.7)$ & $\begin{array}{l}\text { You should only lie in direct sun for as long as you don’t } \\
\text { get sunburnt. }\end{array}$ & $\begin{array}{l}\text { Significant molecular and cellular skin damage occurs already at } \\
\text { suberythemal UVR doses [45]. } \\
\text { (Statement rated as misleading) }\end{array}$ \\
\hline Suntan & $43(7.6)$ & Tanned skin is the best light protector. & $\begin{array}{l}\text { The natural skin protection afforded by tanning upon repeated } \\
\text { UVR exposure is very modest ( SPF 2) [46]. Furthermore, tanning } \\
\text { always comes at the cost of DNA photodamage [26]. } \\
\text { (Statement rated as erroneous) }\end{array}$ \\
\hline
\end{tabular}


Table 3 (continued)

\begin{tabular}{|c|c|c|c|}
\hline $\begin{array}{l}\text { Topic of } \\
\text { inaccuracy }\end{array}$ & $\begin{array}{l}\text { Articles, } \\
\mathrm{n}(\%)^{1}\end{array}$ & $\begin{array}{l}\text { Examples (original quotes from the articles translated } \\
\text { into English) }\end{array}$ & Comment \\
\hline \multirow[t]{2}{*}{ Solarium } & \multirow[t]{2}{*}{$43(7.6)$} & $\begin{array}{l}\text { Modern sun studios have got tanning beds that are, } \\
\text { thanks to new legislation, designed to maximise the } \\
\text { healthy effect of the sun as well as the nice tan effect, } \\
\text { without damaging the skin. }\end{array}$ & $\begin{array}{l}\text { Irrespective of regulations, solaria users are exposed to high levels } \\
\text { of UVR which increase their risk of skin cancer and premature } \\
\text { skin ageing }[47,48] \text {. } \\
\text { (Statement rated as erroneous) }\end{array}$ \\
\hline & & $\begin{array}{l}\text { By systematic pretanning in the solarium with } \\
\text { professional advice, it is possible to heighten the natural } \\
\text { protection of the skin and reduce the risk of getting } \\
\text { sunburnt. }\end{array}$ & $\begin{array}{l}\text { A tan induced by UVA-rich solaria is essentially not protective } \\
\text { against subsequent sun exposure, but per se associated with } \\
\text { cutaneous photodamage [49]. } \\
\text { (Statement rated as erroneous) }\end{array}$ \\
\hline Vitamin D & $120(21.3)$ & $\begin{array}{l}\text { Due to vitamin } \mathrm{D} \text { being produced in the skin, sunbathing } \\
\text { at the beach or in the garden is highly recommendable. } \\
\text { In winter the solarium is an alternative. }\end{array}$ & $\begin{array}{l}\text { Since UVR is a human carcinogen, prolonged sun exposure and } \\
\text { solaria should be avoided. Adequate vitamin D levels can be } \\
\text { obtained from short incidental sun exposure, diet or oral } \\
\text { supplements }[15,48] \text {. } \\
\text { (Statement rated as erroneous) }\end{array}$ \\
\hline Other & $71(12.6)$ & $\begin{array}{l}\text { Research has shown that people who work mostly } \\
\text { outside, like gardeners or farmers, are less likely to } \\
\text { contract skin cancer. }\end{array}$ & $\begin{array}{l}\text { According to two recent meta-analyses, outdoor workers are at } \\
\text { increased risk of developing non-melanoma skin cancer }[52,53] \text {. } \\
\text { (Statement rated as erroneous) }\end{array}$ \\
\hline
\end{tabular}

SPF $=$ Sun protection factor.

${ }^{1} 100 \%$ corresponds to the 564 articles containing misleading or erroneous information. Articles with several inaccurate statements on different topics were counted in all corresponding categories.

2 Time of UVR exposure until the occurrence of sunburn.

vitamin $\mathrm{D}$ articles unsupportive for UVR protection identified in our study, a similar decline in skin cancer preventive behaviours may be expected in Central Europe.

On the whole, the quality of information across all articles included in our content analysis gives rise to concern, with more than every fourth text containing misleading or erroneous statements. Most ascertained inaccuracies pertained to the use of sunscreens, particularly to their correct application and the meaning and implication of the labelled SPF, followed by vitamin D issues. It should be noted that uncertainties about these topics do not only prevail among journalists, but also among the journalists' sources, namely dermatologists and other health professionals. This explains the somewhat elusive finding that articles authored by health professionals were not of better quality than articles authored by journalists.

In summary, the data reported herein provide a broad picture of skin cancer prevention and vitamin D messages made available to the public through German and Swiss print media. The delivered information was generally rath- er superficial and in a considerable number of newspaper and magazine articles misleading or factually incorrect. The latter is partly rooted in persistent misconceptions regarding UVR protection which prevail in the medical community and are subsequently adopted by journalists. To assist the media in disseminating sound skin cancer prevention strategies, health organisations should formulate consistent, easily understandable recommendations based on the current state of science. The uneasy relationship between UVR protection and adequate vitamin D synthesis ought to be pro-actively addressed, since unbalanced reports on this issue may seriously undermine the longstanding efforts of sun safety campaigns.

\section{Disclosure Statement}

C.S. was associated with Spirig Pharma Ltd., Egerkingen, Switzerland. He is a consultant to Galderma SA, Lausanne, Switzerland. 


\section{References}

$>1$ Lomas A, Leonardi-Bee J, Bath-Hextall F: A systematic review of worldwide incidence of nonmelanoma skin cancer. Br J Dermatol 2012;166:1069-1080.

-2 Armstrong BK, Kricker A: The epidemiology of UV induced skin cancer. J Photochem Photobiol B 2001;63:8-18.

$\checkmark 3$ Wehner MR, Chren MM, Nameth D, Choudhry A, Gaskins M, Nead KT, Boscardin WJ, Linos E: International prevalence of indoor tanning: a systematic review and metaanalysis. JAMA Dermatol 2014;150:390-400.

$>4$ Dadlani C, Orlow SJ: Planning for a brighter future: a review of sun protection and barriers to behavioral change in children and adolescents. Dermatol Online J 2008;14:1.

5 Garside R, Pearson M, Moxham T: What influences the uptake of information to prevent skin cancer? A systematic review and synthesis of qualitative research. Health Educ Res 2010;25:162-182.

$\checkmark 6$ Mahler HI: Reasons for using and failing to use sunscreen: comparison among whites, Hispanics, and Asian/Pacific Islanders in Southern California. JAMA Dermatol 2014; 150:90-91.

7 McLeod G, Insch A, Henry J: Reducing barriers to sun protection - application of a holistic model for social marketing. Australasian Marketing J 2011;19:212-222.

$>8$ Hay J, Coups EJ, Ford J, DiBonaventura M: Exposure to mass media health information, skin cancer beliefs, and sun protection behaviors in a United States probability sample. J Am Acad Dermatol 2009;61:783-792.

$>9$ Meissner HI, Potosky AL, Convissor R: How sources of health information relate to knowledge and use of cancer screening exams. J Community Health 1992;17:153-165.

-10 O’Keefe GJ, Boyd HH, Brown MR: Who learns preventive health care information from where: cross-channel and repertoire comparisons. Health Commun 1998;10:2536.

-11 Schwitzer G, Mudur G, Henry D, Wilson A, Goozner M, Simbra M, Sweet M, Baverstock KA: What are the roles and responsibilities of the media in disseminating health information? PLoS Med 2005;2:e215.

$>12$ Dixon H, Warne C, Scully M, Dobbinson S, Wakefield M: Agenda-setting effects of sunrelated news coverage on public attitudes and beliefs about tanning and skin cancer. Health Commun 2014;29:173-181.

13 Kemp GA, Eagle L, Verne J: Mass media barriers to social marketing interventions: the example of sun protection in the UK. Health Promot Int 2011;26:37-45.

$>14$ Geller AC, Zhang Z, Sober AJ, Halpern AC, Weinstock MA, Daniels S, Miller DR, Demierre MF, Brooks DR, Gilchrest BA: The first 15 years of the American Academy of Dermatology skin cancer screening programs: 1985-1999. J Am Acad Dermatol 2003;48:34-41.
15 Gilchrest BA: Sun exposure and vitamin D sufficiency. Am J Clin Nutr 2008;88:570S-577S.

16 WHO: Global solar UV Index: a practical guide. A joint recommendation of World Health Organization, World Meteorological Organization, United Nations Environment Programme and the International Commission on Non-Ionizing Radiation Protection. Geneva, World Health Organization, 2002.

17 Albert MR, Ostheimer KG: The evolution of current medical and popular attitudes toward ultraviolet light exposure. Part 3. J Am Acad Dermatol 2003;49:1096-1106.

18 Borner FU, Schutz H, Wiedemann P: The influence of the UV-index on attitudes toward sun exposure in the German population. J Cancer Educ 2010;25:643-649.

19 Krebs H: Bekanntheit, Verständnis und Beachtung des UV Index. Eine Evaluationsstudie im Auftrag der Krebsliga Schweiz. Zurich, 2008. Available on request at www. krebsliga.ch.

20 Lautenschlager S, Wulf HC, Pittelkow MR: Photoprotection. Lancet 2007;370:528-537.

21 Surber C, Ulrich C, Hinrichs B, Stockfleth E: Photoprotection in immunocompetent and immunocompromised people. Br J Dermatol 2012;167(suppl 2):85-93.

22 Krebsliga Schweiz: Sonnenschutz. Eine Information der Krebsliga. Bern 2015. https:// assets.krebsliga.ch/downloads/1320.pdf (accessed May 30, 2015).

23 Bundesamt für Gesundheit: Ultraviolette Strahlung. Bern. http://www.bag.admin.ch/ uv_strahlung (accessed May 30, 2015).

24 European Skin Cancer Foundation: Sun protection. Berlin. http://www.escf-network.eu/ en/patients/prevention/sun-protection.html (accessed May 30, 2015).

25 Deutsche Krebshilfe: Die Deutsche Krebshilfe rät: Richtig mit der Sonne umgehen. Bonn. http://www.krebshilfe.de/wir-informieren/ ueber-praevention-frueherk/sonne-undhautkrebs.html (accessed May 30, 2015).

26 Miller AJ, Tsao H: New insights into pigmentary pathways and skin cancer. Br J Dermatol 2010;162:22-28.

27 Augustin M, Stadler R, Reusch M, Schafer I, Kornek T, Luger T: Skin cancer screening in Germany - perception by the public. J Dtsch Dermatol Ges 2012;10:42-49.

28 Antonov D, Hollunder M, Schliemann S, Elsner P: UV exposure and protection behavior in the general population: a structured interview survey. Dermatology 2016;1:11-16.

29 Woo DK, Eide MJ: Tanning beds, skin cancer, and vitamin D: an examination of the scientific evidence and public health implications. Dermatol Ther 2010;23:61-71.

30 Wolpowitz D, Gilchrest BA: The vitamin D questions: how much do you need and how should you get it? J Am Acad Dermatol 2006; 54:301-317.
31 Scully M, Wakefield M, Dixon H: Trends in news coverage about skin cancer prevention, 1993-2006: increasingly mixed messages for the public. Aust NZ J Public Health 2008;32: 461-466.

32 Scully M, Makin J, Maloney S, Wakefield M: Changes in coverage of sun protection in the news: threats and opportunities from emerging issues. Health Educ Res 2014;29:378-387.

33 Youl PH, Janda M, Kimlin M: Vitamin D and sun protection: the impact of mixed public health messages in Australia. Int J Cancer 2009; 124:1963-1970.

34 Diffey BL: When should sunscreen be reapplied? J Am Acad Dermatol 2001;45:882-885.

35 International Standard: Cosmetics - sun protection test methods - in vivo determination of the sun protection factor (SPF). ISO 24444 2010.

36 Lademann J, Schanzer S, Richter H, Pelchrzim RV, Zastrow L, Golz K, Sterry W: Sunscreen application at the beach. J Cosmet Dermatol 2004;3:62-68.

37 Petersen B, Datta P, Philipsen PA, Wulf HC: Sunscreen use and failures - on site observations on a sun-holiday. Photochem Photobiol Sci 2013;12:190-196.

38 Wright MW, Wright ST, Wagner RF: Mechanisms of sunscreen failure. J Am Acad Dermatol 2001;44:781-784.

39 Osterwalder U, Herzog B: Sun protection factors: worldwide confusion. Br J Dermatol 2009;161(suppl 3):13-24.

40 Loden M, Beitner H, Gonzalez H, Edstrom DW, Akerstrom U, Austad J, BuraczewskaNorin I, Matsson M, Wulf HC: Sunscreen use: controversies, challenges and regulatory aspects. Br J Dermatol 2011;165:255-262.

41 Van der Pols JC, Williams GM, Pandeya N, Logan V, Green AC: Prolonged prevention of squamous cell carcinoma of the skin by regular sunscreen use. Cancer Epidemiol Biomarkers Prev 2006;15:2546-2548.

42 Thompson SC, Jolley D, Marks R: Reduction of solar keratoses by regular sunscreen use. $\mathrm{N}$ Engl J Med 1993;329:1147-1151.

43 Green AC, Williams GM, Logan V, Strutton GM: Reduced melanoma after regular sunscreen use: randomized trial follow-up. J Clin Oncol 2011;29:257-263.

44 Stahl W, Sies H: Photoprotection by dietary carotenoids: concept, mechanisms, evidence and future development. Mol Nutr Food Res 2012;56:287-295.

45 Seite S, Fourtanier A, Moyal D, Young AR: Photodamage to human skin by suberythemal exposure to solar ultraviolet radiation can be attenuated by sunscreens: a review. $\mathrm{Br} \mathrm{J}$ Dermatol 2010;163:903-914.

46 Sheehan JM, Potten CS, Young AR: Tanning in human skin types II and III offers modest photoprotection against erythema. Photochem Photobiol 1998;68:588-592. 
-47 Autier P, Dore JF, Breitbart E, Greinert R, Pasterk M, Boniol M: The indoor tanning industry's double game. Lancet 2011;377:12991301.

-48 Lim HW, James WD, Rigel DS, Maloney ME, Spencer JM, Bhushan R: Adverse effects of ultraviolet radiation from the use of indoor tanning equipment: time to ban the tan. J Am Acad Dermatol 2011;64:893-902.

49 Miyamura Y, Coelho SG, Schlenz K, Batzer J, Smuda C, Choi W, Brenner M, Passeron T,
Zhang G, Kolbe L, Wolber R, Hearing VJ: The deceptive nature of UVA tanning versus the modest protective effects of UVB tanning on human skin. Pigment Cell Melanoma Res 2011;24:136-147.

50 Kannan S, Lim HW: Photoprotection and vitamin D: a review. Photodermatol Photoimmunol Photomed 2014;30:137-145.

51 Norval M, Wulf HC: Does chronic sunscreen use reduce vitamin $\mathrm{D}$ production to insufficient levels? Br J Dermatol 2009;161:732-736.
52 Schmitt J, Seidler A, Diepgen TL, Bauer A: Occupational ultraviolet light exposure increases the risk for the development of cutaneous squamous cell carcinoma: a systematic review and meta-analysis. Br J Dermatol 2011;164:291-307.

53 Bauer A, Diepgen TL, Schmitt J: Is occupational solar ultraviolet irradiation a relevant risk factor for basal cell carcinoma? A systematic review and meta-analysis of the epidemiological literature. Br J Dermatol 2011;165:612-625. 